\title{
A New Group of Water-soluble Iron-binding Compounds from Mycobacteria: The Exochelins
}

\author{
By L. P. MACHAM AND C. RATLEDGE \\ Department of Biochemistry, University of Hull, $\mathrm{HU}_{7}{ }_{7} \mathrm{RX}$ \\ (Received Io March I975; revised 5 April 1975) \\ INTRODUCTION
}

The iron transport system of Mycobacterium smegmatis involves the participation of at least two iron-binding molecules. The first, mycobactin, which is lipid-soluble, transports iron through the boundary layers of the bacterium (Ratledge \& Marshall, 1972). As mycobactin is not secreted into the medium, a second compound has to be produced to solubilize the iron, which otherwise might not come into contact with the bacteria. Although we had previously supposed that salicylate, which is found almost exclusively in the medium (Ratledge \& Winder, 1962), functions as this external iron scavenger, we have recently shown that its capabilities for this role are limited. In the presence of phosphate, as for example in a basal-salts growth medium, salicylic acid fails to hold iron in solution at physiological pH values (Ratledge et al. 1974). Its function as an iron chelator under such circumstances has therefore been discounted. However, a specific and unrestricted role for salicylate may be to transfer reduced iron (i.e. $\mathrm{Fe}^{2+}$ ) from mycobactin, after its transport to the inner surfaces of the bacterial envelope, to an acceptor molecule such as porphyrin (Brown \& Ratledge, 1975).

This preliminary report describes investigations undertaken to resolve the problem of how $M$. smegmatis solubilizes iron in phosphate-containing medium and the detection of a novel series of water-soluble, iron-binding compounds which, because of their chelating ability and occurrence in the growth medium, have been given the trivial name exochelins.

\section{METHODS}

Organisms and growth. Mycobacterium smegmatis NCIB8548 and M. bovis var. BCG were grown as previously described (Ratledge \& Marshall, 1972), either in shaken $250 \mathrm{ml}$ conical flasks containing $100 \mathrm{ml}$ medium, or in a vortex-aerated fermenter holding $600 \mathrm{ml}$ medium. For iron-deficient growth $\mathrm{Fe}^{2+}$ was at $0.05 \mu \mathrm{g} / \mathrm{ml}$ and for iron-sufficient growth it was at $2 \cdot 0 \mu \mathrm{g} / \mathrm{ml}$.

Estimation of iron-solubilizing compounds in media. Samples (about $5 \mathrm{ml}$ ) of growth culture medium were taken at various times and the bacteria removed by filtration through membrane filters $\left(0.45 \mu \mathrm{m}\right.$ pores). To a $\mathrm{I} \cdot 0 \mathrm{ml}$ portion of the filtrate was added $0.1 \mathrm{ml}{ }^{55} \mathrm{FeCl}_{3}$ solution (IO $\mu \mathrm{g} \mathrm{Fe}^{3+} ; 45 \mathrm{nCi}^{55} \mathrm{Fe}$ ) in $0 . \mathrm{I} \mathrm{M}-\mathrm{HCl}$. The mixture, with a $\mathrm{pH}$ of about $6 \cdot 7$, was allowed to stand for $3 \mathrm{~h}$, then $\mathrm{I} \cdot 0 \mathrm{ml}$ was dialysed through Visking tubing against $10 \mathrm{ml}$ uninoculated growth medium for $20 \mathrm{~h}$ at $20^{\circ} \mathrm{C}$. Samples $(0.5 \mathrm{ml})$ of the dialysate were then taken for radioactive counting. Aqueous samples containing ${ }^{55} \mathrm{Fe}$ were counted by liquid scintillation as previously described (Ratledge et al. 1974). Standard solutions of ${ }^{55} \mathrm{Fe}$ were used to calculate the actual amounts of iron.

Isolation of exochelin. Iron-deficient medium ( $\mathrm{I}$ to 2 l) from three-day-old cultures of 
M. smegmatis was filtered through Whatman GF/A paper. Solid $\mathrm{FeCl}_{3}$ was added in 2 to $3 \mathrm{mg}$ portions until the formation of orange colour was complete and addition of further $\mathrm{FeCl}_{3}$ resulted in a precipitate. The $\mathrm{pH}$ was adjusted if necessary to between $6 \cdot 8$ and $7 \cdot 2$. The medium was left to stand at $3{ }^{\circ} \mathrm{C}$ overnight, then the excess iron was filtered off by passage through GF/C paper. The extinction at $430 \mathrm{~nm}$ of such medium was between 0.3 and 0.5 , whereas the corresponding extinction of filtered medium to which no iron had been added was usually 0.03 to 0.05 .

Ferri-exochelin was isolated from the medium by adjusting the $\mathrm{pH}$ to 3.5 with $\mathrm{HCl}$. The solution was passed through a $7 \times 3 \mathrm{~cm}$ column of Zerolit 225 (SRC IO) sulphonic acid-type ion-exchange resin at about $10 \mathrm{ml} / \mathrm{min}$. The column was washed with about $100 \mathrm{ml}$ water and the exochelin then eluted with $\mathrm{I}$ M aqueous $\mathrm{NH}_{3}$ at about $2 \mathrm{ml} / \mathrm{min}$, which immediately after collection was rotary evaporated under vacuum to dryness.

\section{RESULTS}

Production of iron-solubilizing agents in the medium during growth of mycobacteria

Culture filtrates of $M$. bovis BCG and $M$. smegmatis were examined for iron-solubilizing agents. To maximize formation of any such compounds, the bacteria were grown under iron-deficient conditions. The existence of a compound, or compounds, capable of holding iron in such solutions (determined as dialysable ${ }^{55} \mathrm{Fe}$ ) at a $\mathrm{pH}$ near neutrality was confirmed for both organisms (Table I). The test procedure did not detect any dialysable (i.e. soluble) iron in the uninoculated growth medium. The capacity of $M$. smegmatis culture filtrates to hold iron in solution increased progressively until 5 days' growth, when effectively all the iron added in the test ( $10 \mu \mathrm{g} / \mathrm{ml}$ culture filtrate) was solubilized. Filtrates from cultures of this organism grown under iron-sufficient conditions did not possess such a high capacity for solubilizing iron, although low concentrations of iron were solubilized after three days' growth.

\section{Table I. Capacity of mycobacterial growth media to solubilize iron}

Culture medium (I ml) was mixed with $10 \mu \mathrm{g}^{55} \mathrm{FeCl}_{3}$ and then dialysed against fresh growth medium (see Methods). Samples of the dialysate were counted and the concentration of iron calculated from appropriate standard solutions of ${ }^{55} \mathrm{Fe}$. Both organisms were grown in shakeculture: $M$. smegmatis was fully grown after 5 days, $M$. bovis was almost at the end of growth by 7 days.

\begin{tabular}{|c|c|c|c|}
\hline \multirow{3}{*}{$\begin{array}{l}\text { Age of } \\
\text { culture } \\
\text { (days) }\end{array}$} & \multicolumn{3}{|c|}{$\begin{array}{c}\text { Iron-solubilizing capacity } \\
\text { ( } \mu \mathrm{g} \mathrm{Fe} \text { solubilized/ml medium) }\end{array}$} \\
\hline & \multicolumn{2}{|c|}{ M. smegmatis } & \multirow{2}{*}{$\begin{array}{c}\text { M. bovis } \text { ВCG } \\
\text { Iron-deficient } \\
(0.05 \mu \mathrm{g} \mathrm{Fe} / \mathrm{ml})\end{array}$} \\
\hline & $\begin{array}{l}\text { Iron-sufficient } \\
(2 \cdot 0 \mu \mathrm{g} \mathrm{Fe} / \mathrm{ml})\end{array}$ & $\begin{array}{l}\text { Iron-deficient } \\
(0.05 \mu \mathrm{g} \mathrm{Fe} / \mathrm{ml})\end{array}$ & \\
\hline 0 & $<0 . \mathrm{I}$ & $<0.1$ & $<0.1$ \\
\hline I & $<0 . \mathrm{I}$ & $<0.1$ & $<0 . I$ \\
\hline 2 & $<0 . \mathrm{I}$ & 3.0 & $<0 . I$ \\
\hline 3 & 0.2 & $5 \cdot 5$ & $<0.1$ \\
\hline 5 & 0.2 & $9 \cdot 7$ & 0.6 \\
\hline 7 & ND & ND & $2 \cdot 3$ \\
\hline
\end{tabular}




\section{The nature of the iron-solubilizing compound(s)}

The compounds in culture filtrates of $M$. bovis BCG have not yet been examined in detail but preliminary work has shown them to be distinct from the exochelins from M. smegmatis: unlike the compounds from $M$. smegmatis, they are freely soluble in organic solvents and can be extracted from aqueous media into chloroform. The remainer of this report is devoted to the material isolated from $M$. smegmatis.

When $\mathrm{FeCl}_{3}$ was added to the culture filtrates of $M$. smegmatis grown under iron-deficient conditions, an orange, dialysable compound was formed. The material or its desferri counterpart could not be extracted at $\mathrm{pH} 7$ or $\mathrm{pH} 2$ into organic solvents such as diethyl ether or ethyl acetate. It also failed to partition into $n$-butanol or phenol-chloroform (I:I, w/v) mixture. When isolated after ion-exchange chromatography and evaporated to dryness, the ferri-complex was only sparingly soluble in methanol or ethanol but readily re-dissolved in water to give a deep red solution. A sample of the partially purified ferri-containing material showed no u.v. absorption or fluorescence, confirming that it was not a phenolic or aromatic acid and therefore unrelated to salicylic acid which had previously been conjectured as the external iron-binding compound. The material does not correspond to any of the previously recognized microbial water-soluble iron-binding compounds (Lankford, 1973; Neilands, 1974).

The visible spectrum of ferri-exochelin showed a single broad peak at $430 \mathrm{~nm}$ which was unchanged both in wavelength and extinction between $\mathrm{pH}$ values $2 \cdot 5$ and 9.3 . Beyond these $\mathrm{pH}$ values, simple decolorization took place without a spectral shift to $5 \mathrm{ro} \mathrm{nm}$ which is characteristic of simple ferric hydroxamate (Neilands, 1967). Ferri-exochelin is a basic compound and, by electrophoresis, has a probable pI of 9.3. It was readily reduced in aqueous solution by adding $\mathrm{Na}_{2} \mathrm{~S}_{2} \mathrm{O}_{4} . \mathrm{Fe}^{2+}$ could be removed from the resulting solution by adding bathophenanthroline and subsequently extracting into chloroform. The desferriexochelin solution was a very pale straw colour. Alternatively, iron could be slowly leached from ferri-exochelin by allowing solutions of it to stand for $24 \mathrm{~h}$ in contact with $50 \mathrm{~mm}$-EDTA or $5 \mathrm{~mm}-8$-hydroxyquinoline.

\section{DISCUSSION}

Most micro-organisms have the ability to solubilize iron which, because of its insoluble nature, otherwise may never come into direct contact with the cells. This process is mediated by the secretion of iron-binding compounds which have been described in several organisms (Lankford, I973; Neilands, 1974). In mycobacteria, salicylic acid was originally thought to fulfil this role but the formation of $\mathrm{Fe}^{\mathrm{III}}$ (salicylate) ${ }_{3}$ could not be demonstrated in the culture medium, principally because of competing phosphate ions (Ratledge et al. 1974). Mycobactin has been shown to be unable to solubilize precipitated iron from aqueous media (Ratledge et al. 1974). From the work described here, iron solubilization is achieved by compounds termed exochelins which, at least in $M$. smegmatis, are structurally unrelated to salicyclic acid.

However, exochelin must be able to give up the iron it has solubilized to the bacteria, and this aspect of its function has been demonstrated using purified exochelin from M. smegmatis. We followed the uptake of ${ }^{55} \mathrm{Fe}$, either as ${ }^{55} \mathrm{FeCl}_{3}$ or ${ }^{55} \mathrm{Fe}$-exochelin (prepared by mixing ${ }^{55} \mathrm{FeCl}_{3}$ with desferri-exochelin), into washed, iron-deficient bacteria suspended in ${ }^{\circ} \cdot{ }^{1} \mathrm{M}$ phosphate buffer (see Ratledge et al. 1974). The initial rate of incorporation of iron into the bacteria was three times faster from exochelin than from ${ }^{55} \mathrm{FeCl}_{3}$; the rate of uptake was 
about $50 \mathrm{ng} \mathrm{Fe} / \mathrm{min}$, a rate comparable to that reported previously for iron uptake into growing bacteria (Ratledge \& Marshall, 1972).

These exochelins undoubtedly fall within the broad classification of iron-binding compounds termed siderochromes (Keller-Schierlein, Prelog \& Zahner, 1964). Preliminary examination of the exochelin from $M$. smegmatis showed that it was a mixture of closelyrelated compounds. The major component appeared to be a cyclic hexapeptide containing 3 mol $\epsilon N$-actyl- $\epsilon N$-hydroxylysine (Macham, unpublished work). There may be some functional relationship between the exochelins and the red-brown ferrioxamines which have been isolated from several actinomycetes (Prelog, 1963) including a species described as a nocardia (Keller-Schierlein \& Prelog, 196r). However, the ferrioxamines do not contain $\epsilon N$ hydroxylysine. We thus conclude that exochelins represent a new series of water-soluble, iron-binding compounds.

Exochelins are secreted into the medium in increasing amounts when the mycobacteria are grown under iron-deficient conditions in common with iron-binding compounds of other micro-organisms (Lankford, 1973; Neilands, 1974). After scavenging what iron there may be available, exochelins are then able to transfer the iron directly to the bacterium. This process we imagine will be mediated through mycobactin and further work on the mechanism of iron transfer from exochelin to mycobactin is currently underway in this laboratory.

We thank the Science Research Council (U.K.) for the award of a grant (B/RG/2256) in support of this work and a postdoctoral fellowship for L.P.M. We are indebted to Mrs S. J. Dews for her technical assistance.

\section{REFERENCES}

Brown, K. A. \& RatLedge, C. (1975). The effect of $p$-aminosalicylic acid on iron-transport and assimilation in mycobacteria. Biochimica et biophysica acta $385,207-220$.

Keller-Schierlein, W. \& Prelog, V. (196I). Stoffwechselprodukte von Actinomyceten. Über das Ferrioxamine. Ein Beitrag zur Konstitution des Nocardamins. Helvetica chimica acta 44, 1981-1985.

Keller-Schierlein, W., Prelog, V. \& Zähner, H. (1964). Siderochrome. (Natürliche Eisen (III)-trihydroxamat-Klomplexe). Fortschritte der Chemie organischer Naturstoffe 22, 279-322.

LANKFORD, C. E. (1973). Bacterial assimilation of iron. Chemical Rubber Company: Critical Reviews in Microbiology 2, 273-33I.

NeIlands, J. B. (1967). Hydroxamic acids in nature. Science, New York 156, 1443-1447.

NeIlands, J. B. (1974). Microbial Iron Metabolism. New York: Academic Press.

Prelog, V. (1963). Iron-containing antibiotics and microbic growth factors. Pure and Applied Chemistry 6, $327-338$.

Ratledge, C., Macham, L. P., Brown, K. A. \& Marshall, B. J. (1974). Iron transport in Mycobacterium smegmatis: a restricted role for salicylic acid in the extracellular environment. Biochimica et biophysica acta 372, 39-5I.

RATledge, C. \& Marshall, B. J. (1972). Iron transport in Mycobacterium smegmatis: the role of mycobactin. Biochimica et biophysica acta $279,58-74$.

RATLedGe, C. \& Winder, F. G. (1962). The accumulation of salicylic acid by mycobacteria during growth on an iron-deficient medium. Biochemical Journal 84, 50I-506. 